\title{
Type 2 diabetes remission: How does it work?
}

\author{
Mohd Shahriman bin Ahmad Fuat, Faridah binti Mohd Zin, Zainab binti Mat Yudin \\ Ahmad Fuat MS, Mohd Zin F, Mat Yudin Z. Type 2 diabetes remission: How does it work?. Malays Fam Physician. $2021 ; 16(1) ; 124-128$. \\ https://doi.org/10.51866/cr1026
}

Keywords: diabetes mellitus, remission, therapeutic lifestyle change, metabolic syndrome

\section{Authors:}

Faridah binti Mohd Zin

(Corresponding author)

$\mathrm{PhD}$. Senior Lecturer

Department of Family Medicine

School of Medical Sciences

Universiti Sains Malaysia.

Kota Bharu, Kelantan

Email: faridahz@usm.my

Mohd Shahriman bin Ahmad Fuat

Department of Family Medicine Hospital Universiti Sains Malaysia Kota Bharu, Kelantan

Zainab binti Mat Yudin MMed, Lecturer

School of Dental Sciences Universiti Sains Malaysia Kota Bharu, Kelantan

\section{Abstract}

Type 2 diabetes mellitus (Type $2 \mathrm{DM}$ ) is a chronic disease which rise is closely linked to the obesity epidemic and which requires long-term medical attention to limit the development of its wideranged complications. Many of these complications arise from the combination of resistance to insulin action, inadequate insulin secretion, and excessive or inappropriate glucagon secretion. The increasing evidence of its remission state has been discussed in the literature. Here we report on a patient with metabolic syndrome who underwent a structured therapeutic lifestyle changes (TLC) therapy which eventually led to remission of Type 2 DM.

\section{Introduction}

Type 2 diabetes mellitus (Type $2 \mathrm{DM}$ ) is a non-communicable disease (NCD) which continues to grow in prevalence worldwide despite significant efforts to control and prevent it. In Malaysia, the 2019 National Health and Morbidity Survey (NHMS) reported that $18.3 \%$ of adults over the age of 18 and $20.8 \%$ of adults over the age of 30 suffered from diabetes. ${ }^{1}$ The pathophysiology of Type 2 DM was believed to be characterized by progressive, irreversible loss of pancreatic insulin secretion mediated by apoptosis of pancreatic $\beta$-cells. ${ }^{2,3}$ However, recent studies showed that weight loss can bring restoration of $\beta$-cells response, leading to diabetes remission. ${ }^{2}$ Although there is a growing body of theoretical evidence related to this remission state, only a handful of studies and cases covered in the literature specifically report the effectiveness of therapeutic lifestyle changes (TLC) in managing Type 2 DM. ${ }^{1}$ This study therefore looks at the ability to achieve a remission state through therapeutic lifestyle changes in a patient with Type 2 DM.

\section{Case History}

A 33-year-old female, who had underlying Type 2 DM, hypertension and hyperlipidemia, was referred to the obesity clinic for morbid obesity with a body mass index (BMI) of $41.8 \mathrm{~kg} / \mathrm{m}^{2}$. She was diagnosed with Type $2 \mathrm{DM}$ at the age of 22, after which she was started on oral hypoglycaemic agents. She was noncompliant to medications and had multiple hospital admissions for complication of uncontrolled blood sugar. Her initial HbA1c level at diagnosis in 2009 was $9.8 \%$ which worsened to $12.8 \%$ over the course of almost 10 years. Consequently, her liver transaminases and lipid profile became deranged. After failing to achieve glycemic control, she was started on insulin in 2013. Unfortunately, she continued to not comply to treatment until 2018 when she was admitted for severe diabetic ketoacidosis. Concurrently, her body weight reached 115 $\mathrm{kg}$ with BMI of $41.8 \mathrm{~kg} / \mathrm{m}^{2}$. Moreover, her effort tolerance was significantly reduced with New York Heart Association class 3, which disturbed her daily activities. After that, she became determined to change her lifestyle and agreed to be referred to the obesity clinic at Hospital Universiti Sains Malaysia in December 2018. She was given extensive counseling and an intensive therapeutic lifestyle intervention was planned. She received comprehensive dietary advice, was set up with a personalized exercise regime, and attended individual and group behavioral therapy sessions for six months. On further examination, it was found she had a strong family history of Type $2 \mathrm{DM}$, she worked as a teacher at a secondary school, and denied any history of over-the-counter drug or traditional medication intake. Table $\mathbf{1}$ and $\mathbf{2}$ outline the treatment received and the progress of the parameters measured respectively. 
Table 1. Summary of treatment received, challenges and patient adherence to plan

\begin{tabular}{|c|c|c|c|}
\hline & $\begin{array}{l}\text { Management } \\
\text { recommendation/advised }\end{array}$ & Patient's adherence/preference & Challenges \\
\hline $\begin{array}{l}\text { Dietary } \\
\text { intake }\end{array}$ & $\begin{array}{l}\text { Intensive calorie restriction and } \\
\text { counting. } \\
\text { Referral to dietitian. } \\
\text { Aim for less than } 2000 \mathrm{kcal} \\
\text { per day. } \\
\text { Regular fasting twice a week } \\
\text { (depending on patient's } \\
\text { preference). } \\
\text { Stop consumption of sweet } \\
\text { drinks and encouraged to } \\
\text { drink unlimited amounts of } \\
\text { low-calorie fluids such as water, } \\
\text { coffee and tea. } \\
\text { Low carbohydrate diet. }\end{array}$ & $\begin{array}{l}\text { Strict calorie counting as } \\
\text { advised by dietitian (calories } \\
\text { needed per day: } 1600 \mathrm{kcal} \text { ). } \\
3 \text { main meals daily for } 5 \text { days } \\
\text { per week. } \\
14 \text { hours fasting } 2 \text { times a week } \\
\text { (Monday and Thursday). } \\
\text { Stop consumption of sweet } \\
\text { drinks. } \\
\text { Stopped snacking in between } \\
\text { meals. }\end{array}$ & $\begin{array}{l}\text { Initially, during the } \\
\text { first } 2 \text { months of the } \\
\text { TLC regime, she had } \\
\text { mild hypoglycemic } \\
\text { episodes, but these } \\
\text { did not recur after the } \\
\text { 2-month mark. }\end{array}$ \\
\hline $\begin{array}{l}\text { Physical } \\
\text { activities }\end{array}$ & $\begin{array}{l}\text { Exercise therapy clinic: } \\
\text { Referral to exercise therapy } \\
\text { specialist. } \\
\text { Aerobic and resistance exercise. } \\
\text { Daily exercise, started with } \\
\text { light exercise e.g. brisk walking, } \\
\text { jogging, then stepped up } \\
\text { to running, } 90 \text { minutes per } \\
\text { session. } \\
\text { Advised to gradually increase } \\
\text { her exercise duration rather } \\
\text { than intensity. (resistance } \\
\text { exercise) } \\
\text { Encouraged to join group/ } \\
\text { aerobic exercise therapy e.g. } \\
\text { aero-dance and group hiking. }\end{array}$ & $\begin{array}{l}\text { She began with light exercise } \\
\text { such as walking. } \\
\text { Stepped up the frequency, } \\
\text { intensity and duration every } \\
2-3 \text { weeks. } \\
\text { Attend group exercise, } \\
\text { especially aero dance, } 4-5 \text { times } \\
\text { per week. } \\
\text { Frequency of exercise: daily } \\
\text { - Intensity: moderate } \\
\text { - Duration: } 60-90 \text { minutes } \\
\text { per session. }\end{array}$ & \\
\hline $\begin{array}{l}\text { Behavioral } \\
\text { Therapy }\end{array}$ & $\begin{array}{l}\text { Regular monthly follow-up } \\
\text { with individual and group } \\
\text { therapy. } \\
\text { Motivational interview } \\
\text { counseling for at least } 15 \\
\text { minutes at every visit. } \\
\text {-Behavioral change support } \\
\text { approach using the 5As model } \\
\text { (ask, advise, assess, assist, } \\
\text { arrange). } \\
\text {-Emotional support approach. } \\
\text {-Re-emphasized that obesity is } \\
\text { a result of maladaptive eating } \\
\text { patterns and exercise habits. } \\
\text { Emphasized the important role } \\
\text { of CBT in managing weight } \\
\text { loss such as focusing on the } \\
\text { aim, weight self-monitoring, } \\
\text { calorie-counting diary, and } \\
\text { increasing physical activity. }\end{array}$ & $\begin{array}{l}\text { Motivational interview } \\
\text { approach: } \\
\text { - Empowerment, shared } \\
\text { decision making. } \\
\text { - Emotional and empathy } \\
\text { support. } \\
\text { - Adherence to diet and } \\
\text { physical therapy. } \\
\text { - Avoid maladaptive eating } \\
\text { habit. } \\
\text { - Implement diabetes self-care } \\
\text { such as meal planning, } \\
\text { planned physical activity, } \\
\text { blood glucose monitoring, } \\
\text { taking diabetes medicines, } \\
\text { and managing episodes of } \\
\text { illness. }\end{array}$ & \\
\hline
\end{tabular}

*Shared decision making was implemented during each visit 
Table 2. The progress of the parameters measured

\begin{tabular}{|c|c|c|c|c|c|c|c|c|}
\hline${ }_{\text {Parameters }}$ Visit & $\begin{array}{c}\text { Dec } \\
2018\end{array}$ & $\begin{array}{c}\text { Jan } \\
2019\end{array}$ & $\begin{array}{c}\text { Feb } \\
2019\end{array}$ & $\begin{array}{c}\text { Mar } \\
2019\end{array}$ & $\begin{array}{c}\text { Apr } \\
2019\end{array}$ & $\begin{array}{c}\text { Jun } \\
2019\end{array}$ & $\begin{array}{c}\text { Aug } \\
2019\end{array}$ & $\begin{array}{c}\text { Dec } \\
2019\end{array}$ \\
\hline Weight (kg) & 115 & 108 & 104 & 99 & 96.3 & 94 & 83.4 & 79 \\
\hline HbA1c (\%) & 12.6 & 9.4 & - & - & 4.6 & - & 5.0 & 5.3 \\
\hline $\begin{array}{l}\text { Lipid profile } \\
\text { TC (mmol/L) } \\
\text { TG }(\mathrm{mmol} / \mathrm{L}) \\
\text { LDL }(\mathrm{mmol} / \mathrm{L}) \\
\mathrm{HDL}(\mathrm{mmol} / \mathrm{L}) \\
\end{array}$ & $\begin{array}{l}7.6 \\
3.2 \\
4.8 \\
0.8\end{array}$ & - & - & - & $\begin{array}{l}5.3 \\
1.8 \\
2.2 \\
1.2 \\
\end{array}$ & - & $\begin{array}{c}4.46 \\
0.88 \\
3.01 \\
1.5 \\
\end{array}$ & - \\
\hline $\begin{array}{l}\text { Renal Function } \\
\text { Sodium }(\mathrm{mmol} / \mathrm{L}) \\
\text { Potassium }(\mathrm{mmol} / \mathrm{L}) \\
\text { Urea }(\mathrm{mmol} / \mathrm{L}) \\
\text { Creatinine }(\mu \mathrm{mol} / \mathrm{L}) \\
\end{array}$ & $\begin{array}{l}139 \\
4.4 \\
4.7 \\
66 \\
\end{array}$ & - & - & - & - & - & - & $\begin{array}{l}136 \\
4.8 \\
4.9 \\
64 \\
\end{array}$ \\
\hline $\begin{array}{l}\text { Liver function } \\
\text { AST (U/L) } \\
\text { ALT (U/L) } \\
\text { ALP (U/L) } \\
\end{array}$ & $\begin{array}{l}28 \\
73 \\
79 \\
\end{array}$ & - & - & $\begin{array}{l}18 \\
74 \\
13 \\
\end{array}$ & - & - & - & $\begin{array}{l}15 \\
67 \\
15 \\
\end{array}$ \\
\hline $\begin{array}{l}\text { Assessment of DM } \\
\text { complications }\end{array}$ & \multicolumn{2}{|c|}{$\begin{array}{c}\text { ECG: normal } \\
\text { Funduscopy: normal } \\
\text { Urine protein: trace. } \\
\text { Mild hypoglycemia } \\
\text { episode during first } 2 \\
\text { months of therapy } \\
\end{array}$} & \multicolumn{2}{|c|}{$\begin{array}{c}\text { Foot examination: } \\
\text { normal } \\
\text { No hypoglycemia } \\
\text { symptom. }\end{array}$} & \multicolumn{2}{|c|}{$\begin{array}{l}\text { Urine protein: } \\
\text { negative }\end{array}$} & \multicolumn{2}{|c|}{$\begin{array}{l}\text { ECG: normal } \\
\text { Funduscopy: normal }\end{array}$} \\
\hline $\begin{array}{l}\mathrm{OHA} / \text { insulin regimen } \\
\text { (units) }\end{array}$ & $\begin{array}{c}\text { IR } 24 \\
\text { TDS } \\
\text { IN } 30 \\
\text { ON } \\
\text { MXTR } \\
\text { 1gm } \\
\text { OD }\end{array}$ & $\begin{array}{l}\text { IR } 14 \\
\text { TDS } \\
\text { IN } 24 \\
\text { ON } \\
\text { MXTR } \\
\text { 1gm } \\
\text { OD }\end{array}$ & $\begin{array}{l}\text { IR } 14 \\
\text { TDS } \\
\text { IN } 20 \\
\text { ON }\end{array}$ & $\begin{array}{c}\text { IR } 10 \\
\text { TDS } \\
\text { IN } 20 \\
\text { ON }\end{array}$ & $\begin{array}{c}\text { IR } 8 \\
\text { TDS } \\
\text { IN } 16 \\
\text { ON }\end{array}$ & $\begin{array}{c}\text { IR } \\
-/ 6 / 6 \\
\text { IN } 8 \\
\text { ON }\end{array}$ & \multicolumn{2}{|c|}{ Treatment ceased } \\
\hline
\end{tabular}

Abbreviations:

TC: total cholesterol, TG: total triglycerides, LDL: low-density lipoprotein, HDL: highdensity lipoprotein

AST: aspartate aminotransferase, ALP: alkaline phosphatase, ALT: alanine aminotransferase

OHA: oral hypoglycemic agent, IR: insulin regular, IN: insulin isophane, MTXR: metformin extended release

\section{Discussion}

This case illustrates the effectiveness of therapeutic lifestyle changes in eliminating the need for diabetic medication in a case of longstanding Type 2 Diabetes (Type 2 DM). The patient-centered care concept, as a core of the primary care principle, was utilized throughout the entire process. During each visit, the patient was given the opportunity to outline her preferences for her exercise regime and to discuss any dietary modifications. The practice of shared decision making made the patient more likely to adhere to the treatment. The first official report on the remission of Type 2 DM was made following a bariatric surgery almost a quarter-century ago.,3 More recent research has proved that the diabetes remission state can be achieved by therapeutic lifestyle changes focusing mainly on a strict dietary regime achieving weight loss of approximately $15 \mathrm{~kg}{ }^{3}$ The underlying physiological changes were found to be a result of weight reduction improving the defects in both insulin secretion and hepatic insulin sensitivity of Type $2 \mathrm{DM}^{4}{ }^{4}$ Thus, recent practice involves the use of new exercise regimes, behavioral interventions, and psychosocial care - all considered essential components of the therapeutic lifestyle change (TLC) weight reduction strategy in the treatment of Type 2 DM. $^{4,5}$

Studies have shown that dietary intervention plays the most significant role in weight reduction; in fact, $70 \%$ of weight can be reduced by diet alone. ${ }^{6}$ Options include balanced lowcalorie, low-fat/low-calorie, moderate-fat/lowcalorie, and low-carbohydrate diets, as well as the 
obesity clinic. A multicomponent exercise regime should involve a comprehensive combination of aerobic and resistance training. Nevertheless, the patient's safety upon exercising - including their fitness and cardiovascular risk - should always be taken into consideration before prescribing an exercise regime. Other factors that can affect the structure and intensity of a prescribed exercise regime include existing medical conditions and age. ${ }^{1}$ Another study reported, in those with obesity and Type 2 DM, structured exercise interventions lasting at least 8 weeks can lower $\mathrm{HbA1C}$ by an average of $0.66 \%$ even without a significant change in body weight. ${ }^{11,12}$

Recently, behavioral therapy has been found to be a valuable addition for weight reduction programs. ${ }^{13,14,15}$ Among the recommended behavioral therapies, Cognitive Behavioral Therapy (CBT) is recognized as the first-line treatment to help patients to achieve a longterm involvement in sustainable and successful weight reduction programs. ${ }^{13,14}$ CBT helps in improving diet control, stress management, motivation to exercise, and coping skills, all of which lead to a higher chance of achieving the desired goal. ${ }^{13,14}$ However, due to the extensive nature of the CBT process, which requires 8 to 10 one-hour sessions, it is reasonable to regard motivational interview technique (MIT) as a better choice of behavioral therapy in the primary care setting. ${ }^{14,15}$ MIT is a client-centered approach that promotes behavioral change by exploring ambivalence in a nonjudgmental and supportive yet direct fashion. ${ }^{16,17}$ This feasible primary care technique has been shown to be an effective adjunct therapy to improve adherence to the weight reduction program. ${ }^{16,17}$ In our case, we applied MIT concept at each visit to improve and maintain motivation toward the prescribed regimens. The details of the therapy given are shown in Table $\mathbf{1}$.

Finally, after approximately 8 months of an intensive therapeutic lifestyle changes regimen and a series of regular follow-ups, the patient had fulfilled the criteria of diabetes remission. The remission state of diabetes is defined as when a patient achieves an HbA1c level below 6.5\% while also being able to discontinue all diabetic medications for at least 2 months. ${ }^{3}$ For this patient, her latest $\mathrm{HbA1c}$ level is $4.6 \%$, following which all the diabetic medications were ceased.

\section{Conclusion}

The present case shows that an intensive therapeutic lifestyle regimen can eliminate the need for diabetic medication; thus remission can be achieved in a Type 2 DM patient with obesity without recourse to drugs. A multidisciplinary approach delivered in a patient-centered manner is an effective strategy for achieving weight reduction through a therapeutic lifestyle regimen. Weight reduction with the concurrent increment in physical activities improves diabetic control. Hence, despite the growing medical interventions, therapeutic lifestyle changes should always be an important adjuvant in the treatment of Type 2 DM.

\section{Declaration of patient consent}

The authors certify that appropriate patient consent was obtained.

\section{Financial support and sponsorship}

Nil.

\section{Conflicts of interest}

There are no conflicts of interest to declare.

\section{Acknowledgement}

The author is grateful and acknowledges the valuable contributions of all the helpful coauthors in completing this case report.

\section{How does this paper make a difference to general practice?}

- It demonstrates the effectiveness of therapeutic lifestyles changes (TLC) in reducing insulin resistance, resulting in cessation of diabetic therapy while maintaining diabetic control, thus preventing the complications of Type 2 DM.

- This case illustrates the efficiency of the patient-centered approach in achieving the desired outcome in the management of a chronic medical problem. The shared decision making between the health provider and patient became the center of the behavioral changes process which in turn improved the patient's adherence to treatment and follow-up.

- The use of Motivational Interview Technique, which is feasible in a primary care setting, can promote a better long-term outcome, especially in the management of a noncommunicable disease. 


\section{References}

1. Institute for Public Health. The Fifth National Health and Morbidity Survey 2019 (NHMS IV 2019). Ministry of Health, Malaysia; 2019.

2. Buchwald H, Estok R, Fahrbach K, et al. Weight and type 2 diabetes after bariatric surgery: systematic review and meta-analysis. Am J Med. 2009;122: 248-256.

3. Lean MEJ, Leslie WS, Barnes AC, et al. Durability of a primary care-led weightmanagement intervention for remission of type 2 diabetes: 2-year results of the DiRECT open-label, cluster-randomised trial. Lancet Diabetes Endocrinol. 2019;7(5):344-355 doi:10.1016/S2213-8587(19)30068-3.

4. Lim EL, Hollingsworth KG, Aribisala BS, Chen MJ, Mathers JC, Taylor R. Reversal of type 2 diabetes: normalization of beta cell function in association with decreased pancreas and liver triacylglycerol. Diabetologia, 2011; 54: 2506-2514.

5. American Diabetes Association. Lifestyle management: Standards of Medical Care in Diabetes-2019. Diabetes Care 2019;42(Suppl. 1): S46-S60.

6. Franz MJ, Bantle JP, Beebe CA, Brunzell JD, Chiasson J-L, Garg A, Holzmeister LA, Hoogwerf B, Mayer-Davis E, Mooradian $A D$, Purnell JQ, Wheeler M. Evidence-based nutrition principles and recommendations for the treatment and prevention of diabetes and related complications (Technical Review). Diabetes Care 25: 148-198, 2002.
7. Briggs Early K, Stanley K. Position of the Academy of Nutrition and Dietetics: the role of medical nutrition therapy and registered dietitian nutritionists in the prevention and treatment of prediabetes and type 2 diabetes. J Acad Nutr Diet 2018; 118:34-353.

8. Ku M, Ramos MJ, Fung J. Therapeutic fasting as a potential effective treatment for type 2 diabetes: A 4-month case study. Journal of Insulin Resistance 2017; 1:5

9. Dansinger ML, Gleason JA, Griffith JL, Selker HP, Schaefer EJ. Comparison of the Atkins, Ornish, Weight Watchers, and Zone diets for weight loss and heart disease risk reduction: A randomized trial. JAMA. 2005; 293:43-53.

10. Physical Activity Guidelines Advisory Committee. 2018 Physical Activity Guidelines Advisory Committee Scientific Report. Washington, DC, U.S. Department of Health and Human Services 2018.

11. The American Diabetes Association: Physical activity/exercise and diabetes (Position Statement). Diabetes Care 27 (Suppl. 1): S58S62, 2004.

12. Boulé NG, Haddad E, Kenny GP, Wells GA, Sigal RJ. Effects of exercise on glycemic control and body mass in type 2 diabetes mellitus: a meta-analysis of controlled clinical trials. JAMA 2001; 286:1218-1227.
13. Wilson GT, Wilfley DE, Agras WS, Bryson SW. Psychological treatments of binge eating disorder. Arch Gen Psychiatry. 2010;67(1):94101.

14. Castelnuovo G, Pietrabissa G, Manzoni GM, Cattivelli R, Rossi A, Novelli M, Varallo G, Molinari E. Cognitive behavioral therapy to aid weight loss in obese patients: current perspectives. Psychol Res Behav Manag. 2017 Jun 6;10:165-173

15. Emmons KM, Rollnick S. Motivational interviewing in health care settings. Opportunities and limitations. Am J Prev Med. 2001;20(1):68-74. doi:10.1016/s07493797(00)00254-3.

16. VanWormer J, Boucher J. Motivational interviewing and diet modification: a review of the evidence. Diabetes Educ 30:404-419, 2004.

17. DiLillo VG, Siegfried NJ, West DS. Incorporating motivational interviewing into behavioral obesity treatment. Cogn Behav Pract 10:120-130, 2003 